\title{
S5ynthesis
}

International Scientific Conference of IT and Business-Related Research

\section{THE MODEL OF BUSINESS RESEARCH OF AGRITOURISM POTENTIAL IN RURAL AREAS OF DEVELOPING COUNTRIES}

\author{
MODEL POSLOVNIH ISTRAŽIVANJA POTENCIJALA AGROTURIZMA \\ U RURALNIM OBLASTIMA U ZEMLJAMA U RAZVOJU
}

\author{
Madina Temirbulatova ${ }^{1}$, Mioara Borza ${ }^{2}$ \\ ${ }^{1}$ L.N. Gumilev National Eurasian University, Ministry of Education and Science of the Republic of Kazakhstan \\ ${ }^{2}$ Alexandru Ioan Cuza, University of Iasi, Romania
}

\begin{abstract}
:
Recent changes in agricultural policy in developed countries seem to have strengthened measures to support rural development. Considerable attention is devoted to rural areas due to the fact that they often boast considerable untapped natural and cultural potentials, whose further development would improve the wellbeing of the local inhabitants of rural areas, as well as the overall population. The creation of conditions for sustainable development of rural areas is one of the most important strategic goals of public policy that will ensure the achievement of food security, improve the competitiveness of the national economy and the welfare of citizens.

The development of multifunctionality is identified not only with the economic growth of the rural areas, but also with the improvement of the situation in the field of demography, the quality of life standard of rural population and the overall development of the country, and is associated with the introduction of agriculture with an increasing number of new non-agricultural functions.

This paper defines the concept of "multifunctional development" as the one that refers primarily to sustainable development of rural areas, as well as environmental protection, care of the environment and preservation of the local culture and tradition.

Agritourism is a derivative element of the state social policy, which is closely associated with the areas such as: local government, development of self-regulatory public organizations, and support system to small and medium-sized enterprises. It is considered one of the sources of income diversification of the rural population, as well as one of the factors of poverty reduction strategy in rural areas.
\end{abstract}

\section{Key words:}

multifunctionality, rural areas, sociality, sustainability.

\section{INTRODUCTION}

Globalization has become a key factor characterizing the process of world development. Discussion on the consequences and globalization contradictions relies heavily on the issue of sustainable development. Today, it is of vital importance that the entire world and each state find relevant answers and successfully cope with the powerful global and internal challenges. In the Address of the President of the Republic of Kazakhstan - the Leader of the Nation N.A.Nazarbayev to the people of Kazakhstan "Social and economic modernization - the main vector of development of Kazakhstan" special attention is devoted

\section{Apstrakt:}

Promene u agrokulturalnoj politici u razvijenim zemljama čini se da su ojačale mere za podršku ruralnom razvoju. Tolika pažnja se posvećuje ruralnim oblastima zbog toga što često imaju pozamašne neiskorišćene prirodne i kulturne potencijale, čiji bi razvitak doprineo blagostanju ne samo stanovnika ruralnih krajeva nego i sveukupne populacije. Stvaranje uslova za održivi razvoj ruralnih područja jedan je od najvažnijih strateških ciljeva javne politike koji će grantovati bezbednost hrane, bolju konkurentnost domaće privrede i dobrobit građana.

Razvoj multifunkcionalonosti tumači se ne samo sa ekonomskim rastom ruralnih područja, već i poboljšanjem stanja u oblasti demografije, nivoa kvaliteta života meštana i ukupnog razvoja države povezana je sa uvođenjem poljoprivrede u prostoru sve većeg broja novih nepoljoprivrednih funkcija.

U ovom radu koncept multifuncionalnog razvoja obuhvata prvenstveno održivi razvoj ruralnih područja, kao i zaštitu životne sredine, brigu o životnoj sredini i očuvanju lokalne kulture i tradicije.

Agroturizam je derivativni element državne socijalne politike, koji je tesno povezan sa oblastima kao što su lokalna samouprava, razvoj samoregulativnih javnih organizacija i sistema za podršku malim i srednjim preduzećima. Smatra se jednim od izvora diversifikacije prihoda seoskog stanovništva, kao i jednim od faktora strategije smanjenja siromaštva u ruralnim područjima.

\section{Ključne reči:}

multifunkcionalnost, ruralne oblasti, društvenost, održivost.

to innovations in various segments of the economy as one of the countermeasures directed towards responding properly to the modern globalization issues. The national leader said: «The social importance of projects within the industrial framework - innovative development is absolute; this program remains the main reference point of economic modernization. All state agencies should consider this work as their main care. It is entrusted to the government to provide necessary means for the development of infrastructure of innovative clusters, strengthening of the Kazakhstan innovative system, and the increase in the budgetary expenses for funding perspective scientific researchers through allocation of innovative grants (Nazarbayev $\mathrm{N}, 2010)$. 
The project will allow to further elaborate on the activities necessary for developing additional destinations for tourism growth in Kazakhstan regions in the form of individual agritourism farms, environmental villages, ecological communities and ethnic villages, which will also contribute to the assignment of the leader of the nation, Nursultan Nazarbayev, regarding the preparations for the World Exhibition EXPO-2017, which will be held in Astana and vest agrarian tourism with outsourced functions.

World tourism industry has become significantly globalized and with its rapid dynamics of development, it has become a pretender for the world's leading industry. Since the beginning of the process of tourism intensification and the emergence of its new types, often positioned as a completely independent leisure activity, agritourism has occupied a special place. According to the World Tourism Organization (2011), agritourism is one of the five key strategic directions of a successful global tourism development until 2020. In Europe, rural or agritourism assumes the second place in terms of popularity immediately after the beach tourism and it accounts for about $20-30 \%$ of the total tourism sector revenue. The number of "green" tourists in domestic markets is much higher. For instance, in France, only $7 \%$ of travelers stay at hotels, while the other $93 \%$ prefer to stay at the hotels in rural areas and camping sites.

For Kazakhstan, the use of economic experiences of Central and Eastern Europe is also relevant, which were, at the end of the XX century, on the path of transition from a planned to a market economy towards developing new industry solutions tailored to the peculiarities of natural resources and combining various production factors such as agricultural tourism. Most of the studies in the field of agritourism in these countries were financed by the UNDP (United Nations Development Program), which is the UN's global network in the field development, advocating change in people's lives by providing access to knowledge, experience and resources.

Agritourism, as an example of non-agricultural rural development, is gradually becoming one of the main elements of the multifunctional development of rural areas. For farms, which were traditionally only in charge of agricultural products, tourism is a true opportunity for the improvement of the current situation and prevention of migration to the cities, thus enabling people to get employment in the place where they reside. Multifunctional development policy is called small village industrialization, based on the support and development of non-agricultural initiatives. Agritourism is a derivative element of the state social policy, which is closely associated with the areas such as: local government, development of self-regulatory public organizations, and system support for small and medium-sized businesses. It is considered one of the income diversification sources of the rural population, as well as one of the factors of poverty reduction strategy in rural areas (Sznajder \& Przezbórska, 2006).

Agritourism marketing is evolving in Kazakhstan. The demand of Kazakhstani people is not explored enough in terms of forming an agritourism product relying on the existing tourism potential. A skillful marketing hasn't been conducted yet. There is no sufficient experience to outreach the regional market with its proposal and provide it with necessary advertising, quality standards, guarantees of tourism services, and hence the competitiveness of agritourism sector as a whole. However, international experience shows that agricultural tourism development can be effective in the country from both the social and economic point of view.

\section{PROJECT SCOPE AND OBJECTIVES}

The strategic goal of the project is to improve the quality of life of the population - people of the province and the issue of food security. The aim of this research is to identify the key issues of rural development and initiate appropriate measures of socio-economic, legal and administrative character. These measures will bring the rural areas to a qualitatively new level of development, thus providing a balanced solution to the complex economic, social and environmental objectives while preserving natural resources and historical and cultural potential of the countryside and food security.

The project covered one of the agricultural regions of the developing country (in this case, rural areas of Kazakhstan). This project covers, relative to the capital, Astana, the four geographical research areas: South - Karaganda area, West Kostanai, North - East and Kokshetau - Pavlodar areas within a radius of $100 \mathrm{~km}$, each of which is scheduled for an identical set of scientific research. It is of great importance for these directions, as part of EXPO 2017, to plan and build highways similar to "Astana - Borovoye" highway, which require modern equipment that meets international standards, places of roadside service, and continuous construction of new tourist routes in these areas.

Research within the project is distributed among members of the research groups in seven areas with creation of working sections (groups), whose leaders are the main implementors of the project.

Working sections include the following:

1. Organizational.

2. Geological and geomorphological, GIS research.

3. Zoning and tour-operating.

4. Market research and business planning.

5. Monitoring.

6. Methodological.

7. Project Technical Support

The project should be carried out through mutual participation of the EU experts, who have considerable experience in the development of rural areas in developing countries. The planned studies comply with the legislation of the Republic of Kazakhstan.

It includes a set of measures examined, which involves the following stages:

$1^{\text {st }}$ Stage - Organizational - methodical: It refers to the organizational component of scientific research (working group meetings, budget updating and development of preventive measures for research methodology).

$2^{\text {nd }}$ Stage - Field and forwarding research on the district:

- identification of the most favorable territories for tourism development on the basis of estimation of tourist natural potential;

- definition of priority specializations for each zone and justification of the efficiency of the usage of available resources;

- calculation of ecological capacity of the territory.

$3^{\text {rd }}$ Stage - Cameral - complex processing of statistical and analytical data:

- analysis of a current state of tourism in the given district;

- estimation of tourism impact on socio-economic indexes of the region; 
- calculation of indirect tourism influence on economic development of the region;

- calculation of the forecast and definition of reserves of profitability of the tourist enterprises;

- calculation of tourism impact on the agricultural labor market, including the employability of women and youth in rural areas, unemployment and migration issues;

- calculation of tourism impact on agricultural production and food security;

- Index of improvement of rural livelihoods through the introduction of services in order to combat poverty;

- calculation of environmental safety.

$4^{\text {th }}$ Stage - Design - Marketing and business planning:

- study of the potential demand and offer for tourist services;

- development of the media plan and advertising and information products plan;

- development of the plan on human resources development (training seminars, Master classes, trainings); business plan development of the modeling tourist enterprise.

$5^{\text {th }}$ Stage - Rule-making - approbation of the project results and patent protection:

- preparation for the publication of research results, including organization of conferences and round tables; organization of representation and image actions;

- creation of electronic databases and scientific and technical information funds (Figure 1).

\section{SCIENTIFIC NOVELTY AND RESEARCH METHODOLOGY}

Dedicated methodological approaches to agritourism clusters (ATC) allow us to consider tourism as a subject of study of the modern economy and economic management. For the first time, agricultural tourism is considered a priority trend for tourism specialization of Kazakhstan.

Dedicated methodological approaches to the design of innovative agritourism clusters allow the creation of a generalized qualitative model of a territorial deployment of recreation systems. In the present, Kazakhstan's approach to spatial organization of recreational systems focuses on the concept of territorial recreational system (TRS), which does not take into account the market factors of tourist accommodation facilities and does not include many elements of modern tourism industry in the TRS. The new proposed concept of the model for agritourism cluster development allows us to consider tourism, including agritourism, as a spatial object of study of modern economies and management, which has a subject of interest for both economic and geographical research. The old approach focuses on the creation of an "ideal" TRS, which has become a dogma of the Soviet and traditional Kazakh recreational geography and economy. The proposed model focuses on the objects and subjects of recreation in various social and cultural formations within the particular temporal and spatial frame, while similar research considers TRS as a universal and static spatial phenomenon.

For the first time in the study of tourism, a clear theoretical and methodological alternative has emerged, thus revealing fundamental weaknesses of the concept of territorial recreational systems and the desire to overcome them.

It is expected to conduct a comprehensive study of issues associated with the development of the conceptual and meth-
Research methodology

- application of foresight studies in the studv of the issues and problems of fomation and development of tourism

- cluster-enabling public policies

- cluster-activate public strategy (CAPS)

- mapping using GIS technology, engineering GIS models of the functioning of tourist destinations

- evaluation of direct and indirect effects on the economy of rural tourism and social services regions using primary accounting records and the calculation method tourism multipliers

- calculating the impact of tourism on the agricultural labor market. including the employment of women and youth in rural areas, the problem of unemployment and migration

- calculate the impact of tourism on agricultural production and food security

- calculation indirect impact of tourism on the economv of the region

- Index improve rural livelihoods from the introduction of services in order to Combat poverty

- calculation environmental safety

THE MODEL OF BUSINESS RESEARCH AGRITOURISM ON RURAL AREAS IN THE VELOPING COUNTRIES

Stage - Organizational methodical:

- It refers to the organizational component of scientific research (working group meetings, budget updating and development of preventive measures for research methodology);

- definition of system problems drawing up of forecast and research hypothesis.

$2^{\text {nd }}$ Stage - Field and forwarding

research on the district

- identification of the mos

favorable territories for tourism

development on the basis of

estimation of tourist natural potential;

- definition of priority

specializations for each zone an justification of the efficiency of the usage of available resources:

calculation of ecological capacity of the territory.

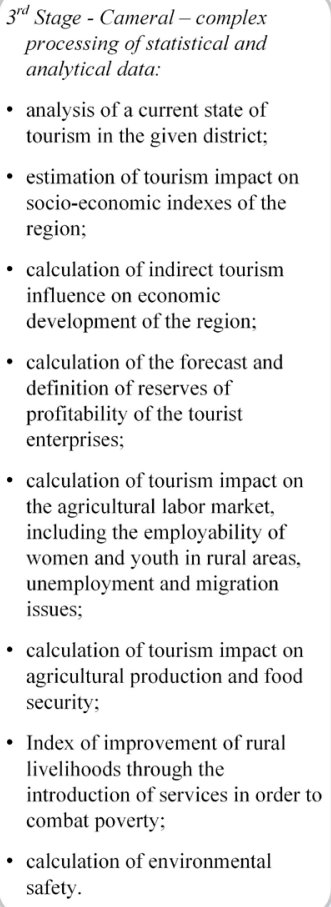
processing of statistical and analytical data:

analysis of a current state of tourism in the given district:

- estimation of tourism impact on socio-economic indexes of the region:

- calculation of indirect tourism influence on economic development of the region;

- calculation of the forecast and definition of reserves of profitability of the touris enterprises;

calculation of tourism impact on the agricultural labor market, including the employability of women and youth in rural areas, unemployment and migration issues:

- calculation of tourism impact on agricultural production and food security;

- Index of improvement of rural livelihoods through the introduction of services in order to combat poverty;

calculation of environmenta safety.

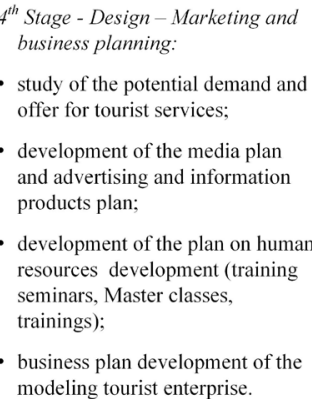
offer for tourist services;

- development of the media plan and advertising and information products plan;

development of the plan on human resources development (training seminars, Master classes, trainings);

- business plan development of the modeling tourist enterprise.

$5^{\text {th }}$ Stage - Rule-making approbation of the project results and patent protection:

preparation for the publication of research results, including organization of conferences and round tables;

organization of representation and image actions;

creation of electronic databases and scientific and technical information funds. 
odological fundamentals of the creation of highly effective and competitive agritourism cluster in the Republic of Kazakhstan and development of the mechanism of investment and management (governance) for territorial recreation systems (TRS).

Research methodology includes:

- application of foresight studies in the study of the issues of formation and development of tourism:

1. Formation of an object

2. Formation of the essential conditions

3. Scan

4. Alternatives of the future

5. Planning and execution;

- the use of the "cluster-enabling public policies, clusteractivate public strategy (CAPS)", since it is a network organization of economic cooperation, to adapt to any changes in the internal and external environment to the optimal distribution of focal growth, conjugation intellectual capital requirements of scientific and technical progress, can provide innovative breakthrough territory's economy, a satisfactory solution to the main problems of any production process and ensure its sustainability and reproduction (Porter, 1980);

- mapping using GIS technology, engineering GIS models of the functioning of tourist destinations;

- evaluation of direct and indirect effects on the rural tourism economy and social services regions using primarily accounting records and the calculation method tourism multipliers;

- calculation of the impact of tourism on the agricultural labor market, including the employment of women and youth in rural areas, the unemployment and migration issues;

- calculation of tourism impact on agricultural production and food security;
- calculation of indirect impact of tourism on the economy of the region;

- Index to improve rural livelihoods from the introduction of services in order to combat poverty;

- calculation of environmental safety.

Thus, as a result of the research, we propose the following Model of a regional cluster of agro-tourism (Figure 2.)

\section{CONSLUSION}

The aassessment of the potential impact of the proposed research in the near to medium term.

Potential research conventionally divided as effects:

a) "Regional economy" specialization:

1. The importance and position of agritourism are revealed as important social and economic factors in the development of the region, which indicates the unique role of agritourism in the development of human capital and infrastructural complex of the region.

2. Guidelines and methodological approaches to zone the territory by social and industrial infrastructure are developed, as well as the availability of natural and recreational resources for the development of measures to improve its utilization and maximum satisfaction of customer demand for tourism services.

3. Methodological principles of strategic management of agritourism are suggested at the regional level; the tasks and functions for the administrative arrangements which are responsible for formation and utilization of agritourism resources are defined.

4. Conceptual framework and mechanisms of resource support areas of agritourism are developed.

5. Incentive tools are proposed for accelerating the deployment of innovative products and technologies in the field of tourism.

\section{MODEL OF REGIONAL CLUSTER AGRITOURISM}

Related and supporting industries

Souvenir production

Banking services

Logistics

Retail

Pharmacy

Center for Security

Altemative Energy

Water treatment technology

Biotechnology

Greenhouse

Advertising center

Plant for waste disposal

Register property
Preferences for the Special Economic

Zone

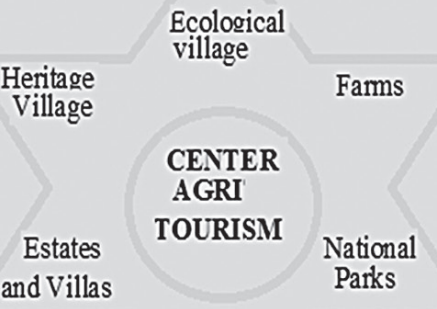

Ministry of A griculture

The Ministry of Labour and Social Protection

Ministry of the Environment

Ministry for Regional Development

Ministrv of Tourism and Sports

Regional Municipality

Bank of innovative products

«L.N. Gumilev National

Eurasian University»

Republic of Kazakhstan
"Alexandru Ioan Cuza" University of Iasi (Romania)
Tourism Association

Travel Agents 
b) Specialization "Economics, organization and management of enterprises, branches, complexes of services":

1. The theoretical basis for the formation of resource support agritourism, including clarification of such fundamental concepts as "agritourism product" and" agritourism market” from the point of social, economic and institutional approaches as the most important characteristics of the consumer sector.

2. The main directions of the development of agritourism; Methodological approaches and best practices in improving regulations, mechanisms to enhance fund raising, development, information management, business support, creating a system of continuing education training in the field of agritourism.

The expected social impact:

Creating the conditions for social stability in rural areas of Kazakhstan.

1. Improving the quality of tourist services as a key element of services development in rural areas.

2. Expansion of the rural employment and creation of new jobs.

3. The preservation and revival of cultural heritage (traditions, rituals, crafts, nature monuments, history, religion, and culture).

The expected economical impact:

1. To increase the economic role of rural tourism in the recreational sector of the country and create a multiplier effect (development associated with recreational activities of the tourism industries).

2. Assistance in attracting foreign and domestic investors in the development of rural tourism.

3. Improving economic efficiency and protection of the existing cultural, historical, recreational and spa resources.

4. Implementation of agritourism in the control of economic methods to stimulate the development of tourism accommodation, native arts and crafts in rural areas (preferential tariffs, preferential loans, implementation of the program of partial compensation of interest on loans, an economic development fund as part of agro-enterprise development support, etc.).

5. Creation of an integrated system of information support agritourism committed to providing the subjects of tourist activity with effective marketing promotion services.

6. Support for the creation of rural modern accommodation agriturism certified quality services in accordance with the common Kazakh standards.

7. ATK support for the winter season, in order to secure employment and meet the demands of the consumers on a short vacation in the suburban areas of large cities.

The expected ecological impact:

1. Effective use, protection and restoration of natural recreational resources of the region as an important part of its natural resources.

2. Minimize human impact of tourism on the natural environment and the health of the population of the province. A decisive role in ensuring the effective agritourism is a combination of natural and socioethnic attractions of a particular area.

\section{REFERENCES}

Nazarbaev, N. (2012). Strategy Kazakhstan 2050: New political course of the established state. Astana, Kazakhstan.

Porter, M. E. (1980). Competitive strategy: Techniques for analyzing industries and competitors. New York: Free Press.

Sznajder, M., \& Przezbórska, L. (2006). Agro-tourism. Warszawa: Polkie Wydawnictwo Ekonomiczne.

World Tourism Organization. (2011). Annual report. Madrid: World Tourism Organization. 